\title{
A Rare Complication Occurring Years After Thyroid Surgery: A Cutaneous Fistula
}

\author{
Tiroit Cerrahisinden Yıllar Sonra Ortaya Çıkan Nadir Bir \\ Komplikasyon: Deri Fistülü
}

\author{
(D) Mustafa Ünübol ${ }^{1}$, Ahmet Orhan Çelik ${ }^{2}$, Adem Maman ${ }^{3}$, Çiğdem Kalaycık Ertugay ${ }^{4}$ \\ ${ }^{1}$ Adnan Menderes University Faculty of Medicine, Department of Internal Diseases, Division of Endocrinology and Metabolic Diseases, Aydın, Turkey \\ ${ }^{2}$ Tokat State Hospital, Clinic of Radiology, Tokat, Turkey \\ ${ }^{3}$ Tokat State Hospital, Clinic of Nuclear Medicine, Tokat, Turkey \\ ${ }^{4}$ Tokat State Hospital, Clinic of Otorhinolaryngology, Tokat, Turkey
}

Keywords

Thyroid surgery, cutaneous fistula, complication

Anahtar Kelimeler

Tiroid cerrahisi, deri fistülü, komplikasyon

Received/Geliş Tarihi : 09.01.2015

Accepted/Kabul Tarihi : 22.06.2015

doi:10.4274/meandros.2046

Address for Correspondence/Yazışma Adresi: Mustafa Ünübol MD,

Adnan Menderes University Faculty of Medicine, Department of Inernal Diseases, Division of Endocrinology and Metabolic Diseases, Aydın, Turkey

E-mail :drmunubol@yahoo.com.tr ORCID ID: orcid.org/0000-0002-6444-3500

This case was presented as poster presentation at $36^{\text {th }}$ Turkey Endocrinology and Metabolism Diseases Congress at 21-25 May 2014 in Antalya.

(C) Meandros Medical and Dental Journal, Published by Galenos Publishing House.

This is article distributed under the terms of the

Creative Commons Attribution NonCommercial 4.0

International Licence (CC BY-NC 4.0).

\section{Abstract}

The mortality and morbidity of thyroid surgery are low. The complications after thyroid surgery include bleeding, wound site infection, keloid formation, recurrent laryngeal nerve and superior laryngeal nerve injury, temporary and permanent hypocalcemia, and injury to surrounding structures such as esophagus, artery, vein and the cervical sympathetic trunk.

Other much rare complication includes cutaneous fistula formation. In this report, we describe a patient who underwent thyroid surgery and developed cutaneous fistula in the late postoperative period, a complication that has never been reported previously following thyroid surgery.

Öz

Tiroid cerrahisi düşük mortalite ve morbiditeye sahiptir. Tiroid cerrahisi sonrası görülen komplikasyonlar; kanama, yara yeri enfeksiyonu, keloid oluşumu, rekürren laringeal sinir ve süperior laringeal sinir hasarı, geçici ve kalıcı hipokalsemi, özofagus, arter, ven ve servikal sempatik zincir gibi çevre yapılarda zedelenmedir. Deri fistülü gelişmesi çok nadir bir komplikasyondur. Bu makalede, tiroid cerrahisi uygulanmış ve geç postoperatif dönemde tiroid cerrahisi sonrası daha önce bildirilmemiş bir komplikasyon olarak deri fistülü gelişmiş bir olgu tanımlanmıştır.

\section{Introduction}

Thyroid surgery is a safe procedure with low mortality and morbidity (1). The most common complications after thyroid surgery are post-operative hypocalcemia and recurrent laryngeal nerve injury (2). Cutaneous fistula developing from thyroidectomy incision scar is not among the known complications (3). We observed that a 57-yearold female patient developed cutaneous fistula from the incision scar 21 years after the thyroid surgery she had undergone. This case is being reported because it is an unexpected late complication following thyroid surgery. 


\section{Case Report}

The 57-year-old female patient had undergone thyroid surgery 21 years ago. The patient presented with yellow-colored discharge that was spontaneous and occurred without trauma, from an area about 1.5 $\mathrm{cm}$ in diameter on the thyroidectomy incision scar. A tract covering an area of about $1.5 \mathrm{~cm}$ was seen to have developed on the patient's thyroidectomy scar (Figure 1). There was no discharge. Ultrasonography was performed and demonstrated a hypoechoic nodule, $5 \mathrm{~mm}$ in diameter, in the right in a heterogeneous internal structure, sized $7 \times 9 \times 18 \mathrm{~mm}$, in the left and $16 \times 16 \times 38 \mathrm{~mm}$ in the right, as well as a residual thyroid tissue with heterogeneous internal structure containing coarse calcifications in an approximately $8 \mathrm{~mm}$ area in the right. There was an approximately $1.5 \mathrm{~cm}$ fistulized tract in the skin in the midline. It was considered that the tract ended in a blind end, and echogenicities with air values were determined in it. Neck magnetic resonance imaging was taken and demonstrated an area that was $1 \mathrm{~cm}$ in diameter which showed peripheral contrast substance uptake in post-contrast analyses, which was hypointense in the T1A sequence and hyperintense in the T2A sequence with no apparent association with trachea, thyroid gland and other anatomical bodies located in the subcutaneous fatty tissue at the level of the isthmus location in the thyroid. This area was extending to the skin. Thyrotrophin-stimulating hormone, sT4, sedimentation, C-reactive protein and white blood cells in whole blood count were normal. Patient's follow up demonstrated no persistent discharge, but two black suture materials came out of a $1.5 \mathrm{~cm}$ area on day 7 (Figure 2). The tract closed spontaneously without requiring any surgical intervention and the patient is currently under follow up with no problems.

Written consent regarding publication of the findings and photos was received from the patient.

\section{Discussion}

Bleeding, wound site infection and keloid formation are general complications following surgery. Specific complications after thyroid surgery are injury of recurrent laryngeal nerve and the outer branch of the superior laryngeal nerve, transient and permanent hypocalcemia, and injury to the surrounding tissue (3). In a large series including 14.934 cases evaluating

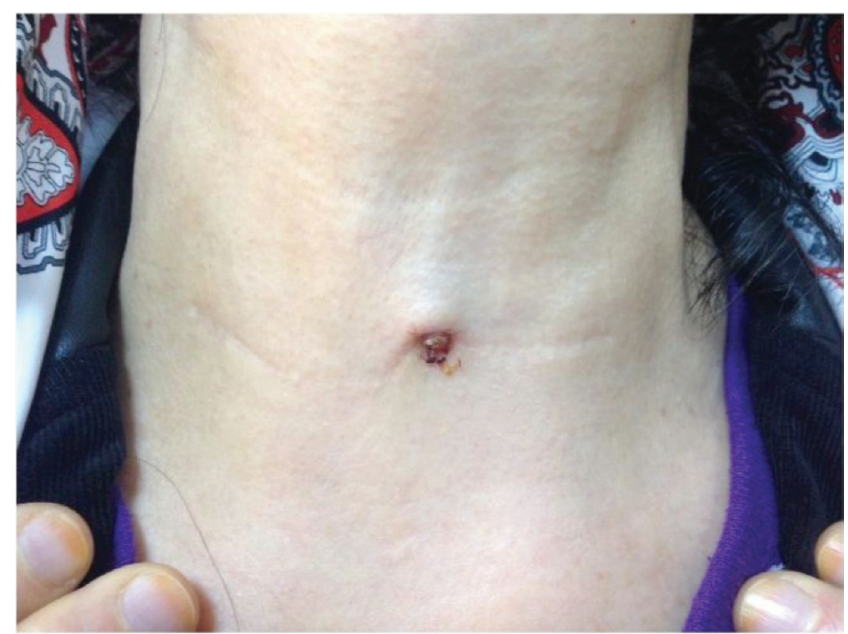

Figure 1. Cutaneous fistula on the thyroidectomy incision scar

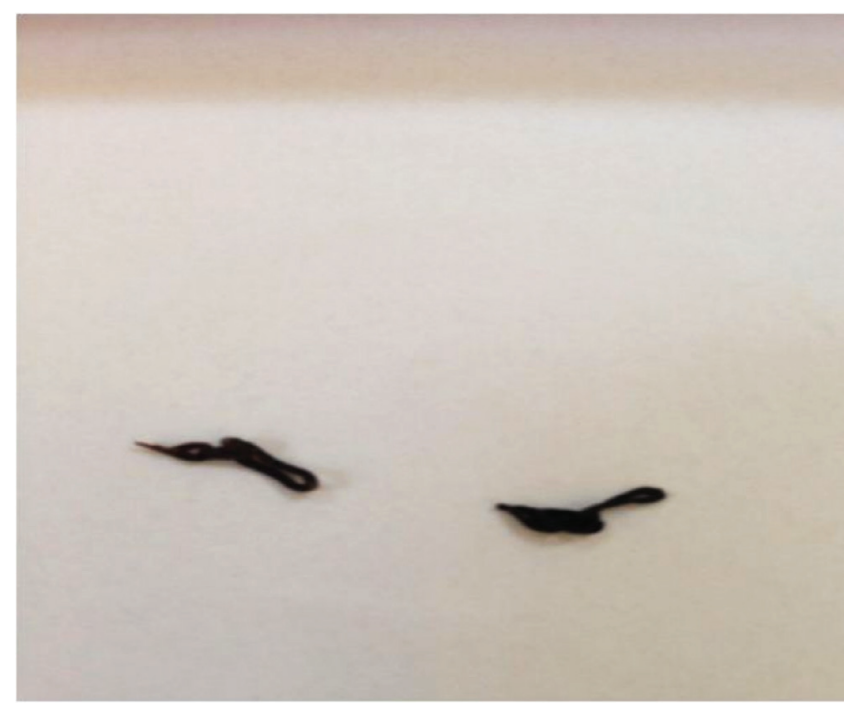

Figure 2. Two black suture materials coming out of the cutaneous fistula

complications following thyroid surgery, transient hypoparathyroidism was reported in $8.3 \%$, permanent hypoparathyroidism in $1.7 \%$, recurrent permanent injury of the laryngeal nerve in $1 \%$, transient injury in $2 \%$, superior laryngeal nerve injury in $3.7 \%$, diplegia, dysphagia, bleeding, and wound site infection very rare (4). Cutaneous fistula was not observed in this series. Likewise, a study by Bergenfelz et al. (5) which evaluated 3.660 cases did not report cutaneous fistula following thyroid surgery. A literature search revealed that different complications than anticipated occurred following thyroid surgery. Hypopharyngeal fistula (6), Horner's syndrome, chylous leakage fistula $(7,8)$, flap edema (7) and seroma (8) are rare complications following thyroidectomy. With literature search, 
there was no report of suture material spontaneously causing fistula in the skin years after thyroid surgery. Non-absorbable multifilament sutures are black, and was used in cutaneous, subcutaneous and fascia repairs in the past. It is, however, not preferred much currently. It may result in fistula tract, hypertrophic scar and infection if left for a long time in the skin (9). In our patient, we thought that the black suture material coming out of the cutaneous fistula was a non-absorbable multifilament suture. We believe that this suture material was used in the thyroid surgery performed 21 years ago and was left under the skin.

Development of a fistula and suture material coming out of the fistula years after thyroid surgery was considered to be a very rare late complication. With this case, we report for the first time in the literature that cutaneous fistula can be seen as a late complication of thyroid surgery. In addition, we would like to emphasize that suture material left under the skin could be one of the causes when fistula develops from a thyroidectomy scar years after the procedure and that the fistula can close spontaneously without surgical intervention.

Ethics

Informed Consent: Was obtained from patient who participated in this case.

Peer-review: Externally and internally peerreviewed.

\section{Authorship Contributions}

Surgical and Medical Practices: M.Ü., Ç.K.E., A.O.Ç., A.M., Concept: M.Ü., Design: M.Ü., Data Collection or Processing: M.Ü., Analysis or Interpretation: M.Ü., Ç.K.E., Literature Search: M.Ü., Ç.K.E., Writing: M.Ü., Ç.K.E.

Conflict of Interest: No conflict of interest was declared by the authors.
Financial Disclosure: The author declared that this study has received no financial support.

\section{References}

1. Nawrot I, Pragacz A, Pragacz K, Grzesiuk W, Barczyński M. Total thyroidectomy is associated with increased prevalence of permanent hypoparathyroidism. Med Sci Monit 2014; 20: 167581.

2. Acun Z, Cihan A, Ulukent SC, Comert M, Ucan B, Cakmak GK, et al. A randomized prospective study of complications between general surgery residents and attending surgeons in near-total thyroidectomies. Surg Today 2004; 34: 997-1001.

3. Lal G, Clark OH. Endocrine surgery. In: Gardener DG, Shoback D, editors. Greenspans's Basic \& Clinical Endocrinology, 9th ed. The McGraw-Hill Companies, China. 2011: 809-11.

4. Rosato L, Avenia N, Bernante P, De Palma M, Gulino G, Nasi PG, et al. Complications of thyroid surgery: analysis of a multicentric study on 14,934 patients operated on in Italy over 5 years. World J Surg 2004; 28: 271-6.

5. Bergenfelz $A$, Jansson $S$, Kristoffersson $A$, Mårtensson $H$, Reihnér E, Wallin $G$, et al. Complications to thyroid surgery: results as reported in a database from a multicenter audit comprising 3,660 patients. Langenbecks Arch Surg 2008; 393: 667-73.

6. Rabie ME. Hypopharyngeal fistula complicating difficult thyroidectomy for invasive papillary cancer. Ann R Coll Surg Engl 2014; 96: e24-6.

7. DU W, Liu ST, Li P, Sun LY, Zhao $M$, Qi JX, et al. Intra- and postoperative complications in 137 cases of giant thyroid gland tumor. Oncol Lett 2012; 4: 965-9.

8. Lee YS, Nam KH, Chung WY, Chang HS, Park CS. Postoperative complications of thyroid cancer in a single center experience. J Korean Med Sci 2010; 25: 541-5.

9. Weinzweig N, Weinzweig J. Basic principles and techniques in plastic surgery. In: Cohen M ed. Mastery of Plastic and Reconstructive Surgery. 1st ed. New York: Little Brown 1994: 1433. 